\title{
MicroRNA-128-2 targets the transcriptional repressor E2F5 enhancing mutant p53 gain of function
}

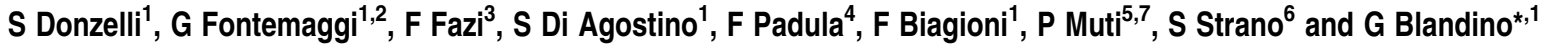

p53 mutations have profound effects on non-small-cell lung cancer (NSCLC) resistance to chemotherapeutic treatments. Mutant p53 proteins are usually expressed at high levels in tumors, where they exert oncogenic functions. Here we show that p53R175H, a hotspot p53 mutant, induces microRNA (miRNA)-128-2 expression. Mutant p53 binds to the putative promoter of miR128-2 host gene, ARPP21, determining a concomitant induction of ARPP21 mRNA and miR-128-2. miR-128-2 expression in lung cancer cells inhibits apoptosis and confers increased resistance to cisplatin, doxorubicin and 5-fluorouracyl treatments. At the molecular level, miR-128-2 post-transcriptionally targets E2F5 and leads to the abrogation of its repressive activity on $21^{\text {waf1 }}$ transcription. p2 $1^{\text {waf1 }}$ protein localizes to the cytoplasmic compartment, where it exerts an anti-apoptotic effect by preventing pro-caspase-3 cleavage. This study emphasizes miRNA-128-2 role as a master regulator in NSCLC chemoresistance.

Cell Death and Differentiation (2012) 19, 1038-1048; doi:10.1038/cdd.2011.190; published online 23 December 2011

Mutations in the TP53 gene are the most frequent type of gene-specific alterations in human cancers. ${ }^{1}$ The majority of cancer-associated mutations in TP53 gene are missense mutations that reside mainly in the exons encoding for p53 DNA-binding domain. ${ }^{2}$ These mutations frequently result in full-length mutant p53 proteins incapable of activating p53 target genes and suppressing tumorigenesis. ${ }^{3}$ Most TP53 mutations can be classified into two main categories according to their effect on the thermodynamic stability of the p53 protein. ${ }^{4}$ These two mutation categories are commonly referred to as DNA-contact and conformational mutations. The first group includes mutations in residues directly involved in DNA binding, such as $\mathrm{R} 248 \mathrm{Q}$ and $\mathrm{R} 273 \mathrm{H}$. The second group comprises mutations that cause local (such as R249S and G245S) or global (such as $\mathrm{R} 175 \mathrm{H}$ and $\mathrm{R} 282 \mathrm{~W}$ ) conformational distortions.

Besides losing their wild-type (wt) activities, mutant p53 proteins have also dominant-negative effects that inactivate wt p53 protein expressed from the remaining wt allele. Moreover, some mutant p53 forms also acquire new oncogenic properties - 'gain of function' - that overrule those due to loss of wt p53 activity by gene deletion. ${ }^{5-7}$ These properties range from enhanced proliferation in culture and resistance to a variety of anticancer drugs commonly used in the clinical practice, to increased tumorigenicity in vivo. ${ }^{8-10}$ Recent work indicates that mutant p53 protein can augment in vitro and in vivo cell migration and invasion. ${ }^{11}$ Fontemaggi et al. ${ }^{12}$ showed that mutant p53 increases also the angiogenic potential of cancer cells by modulating, at the transcriptional level, Id4 expression.

The existing knowledge regarding the molecular mechanisms whereby mutant p53 regulates gene expression is still lacking. To date, we can depict the three following molecular scenarios to explain gain-of-function of mutant p53 proteins: (i) mutant p53 binds to the promoter of its target genes by interacting with other transcription factors and contribute to transcriptional modulation through its intact transactivation domain. In support to this molecular mechanism it has been reported that human tumor-derived p53 mutants whose TAD was inactivated by site-directed mutagenesis, lost the ability to increase tumorigenicity in vitro and in vivo. ${ }^{1,13-15}$ Several sequence-specific transcription factors, such as $\mathrm{Sp} 1,{ }^{16} \mathrm{Ets}$ proteins family, ${ }^{17} \mathrm{NF}-\mathrm{Y},{ }^{18}$ VDR, p65NF- $\kappa \mathrm{B}$ and $\mathrm{E} 2 \mathrm{~F} 1,{ }^{12}$ have been shown to interact with mutant p53 so far. (ii) Mutant p53 binds to and sequesters proteins with antitumor activity, such as growth inhibition or apoptosis induction. At this regard, it has been demonstrated that mutant p53 binds to its family members, p63 and p73, impairing their transcriptional activity and consequently their antitumoral effects. ${ }^{19-22}$ (iii) Mutant p53 protein, for which the attempts to delineate a specific DNA-binding sequence distinct from those regulated by wt p53 have failed, has been reported to directly bind a wide range of DNA secondary structures, such as matrix attachment regions with a high potential of base unpairing in vitro, ${ }^{23}$ or non-B DNA structures. ${ }^{24}$ This might imply that chromatin

\footnotetext{
${ }^{1}$ Translational Oncogenomics Unit, National Cancer Institute 'Regina Elena' Rome, Italy; ${ }^{2}$ General Pathology Section, Department of Clinical and Experimental Medicine, Perugia University, Perugia, Italy; ${ }^{3}$ Department of Medico-Surgical Science and Biotechnologies, Sapienza University of Rome, Latina, Italy; ${ }^{4}$ Section of Histology and Medical Embryology, DAHFMO, Sapienza University of Rome, Rome, Italy; ${ }^{5}$ Department of Epidemiology, National Cancer Institute 'Regina Elena' Rome, Italy and ${ }^{6}$ Molecular Chemoprevention Group, Scientific Direction, National Cancer Institute 'Regina Elena' Rome, Italy

*Corresponding author: G Blandino, Translational Oncogenomics Unit, Regina Elena Cancer Institute, Via Elio Chianesi, 53, 00144-Rome, Italy.

Tel: + 390652662878 (extn: 5327); Fax: + 3906 52665523; E-mail: blandino @ifo.it

${ }^{7}$ Current address: Department of Oncology, Juravinski Cancer Center McMaster University Hamilton, Ontario, Canada.

Keywords: chemoresistance; E2F5; microRNA-128-2; mutant p53; NSCLC; p21waf1

Abbreviations: NCSL, non-small-cell lung cancer; wt, wild-type; miRNA, microRNA; TSS, transcription start site; ChIP, chromatin immunoprecipitation; CDDP, cisplatinum; DOXO, doxorubicin; 5-FU, 5-fluorouracil; Pon-A, ponasterone

Received 05.8.11; revised 07.11.11; accepted 16.11.11; Edited by M Oren; published online 23.12.11
} 
remodeling may be involved in transcriptional activities mediated by mutant $\mathrm{p} 53$ protein.

In the present study, we explored the possibility that mutant p53 protein, in addition to the transcriptional modulation of genes involved in the control of tumorigenesis, exerts its gainof-function activity by modulating the expression of microRNAs (miRNAs). miRNAs are 22-nucleotides-long double-strand small RNAs able to modulate gene expression at posttranscriptional level, degrading mRNA and/or impairing translation. ${ }^{25}$ Many data suggest that miRNAs are key components of a wide range of biological processes, including pathways leading to neoplastic transformation. ${ }^{26}$ In particular, the involvement of miRNAs in the pathogenesis of cancer was suggested by the observation that changes in miRNAs expression patterns, as well as recurrent amplification/deletion at their loci, are frequent events in human tumors. ${ }^{27-29}$

By screening the expression of miRNAs known to be deregulated in lung cancer, ${ }^{28}$ in a human non-small-cell lung cancer (NSCLC) cell line (H1299) expressing the inducible mutant p53His 175 protein, we found that the expression of intragenic miR-128-2 increases upon mutant p53His 175 protein induction. We observed that mutant p53His175 is recruited on the promoter region of miR128-2 host gene, ARPP21, determining a concomitant induction of ARPP21 mRNA level.

The expression of the transcriptional repressor E2F5, a target of miR-128-2, strongly decreases after miR-128-2 exogenous expression. This leads to the abrogation of E2F5 repressive activity on $\mathrm{p} 21^{\text {waf } 1}$ promoter and, consequently, to the transcriptional induction of $\mathrm{p} 21^{\text {waf1 }}$. The newly synthesized p $21^{\text {waf1 }}$ protein is mainly localized into the cytoplasmic compartment, where it exerts an anti-apoptotic function in response to anticancer drug treatments. Interestingly, miR-128-2 effects are observed also in p53-wt and p53-null cells.

These data indicate that miR-128-2 modulation contributes to mutant p53His175 gain-of-function activity by conferring increased chemoresistance of lung cancer cells.

\section{Results}

Mutant p53His175 induces miR-128-2 expression. To investigate whether mutant p53 proteins exert gain-offunction activity through the modulation of miRNAs expression, we screened human NSCLC cells carrying ponasterone (Pon-A)-inducible mutant p53His175 (H1299 no. 41) protein for the expression of a panel of miRNAs differentially represented in lung cancers versus normal tissues (Figure 1a). ${ }^{28}$ As shown in Figure $1 \mathrm{a}$ and Supplementary Figure $1 \mathrm{~A}$, mutant p53 upregulates the expression of miR-128-2. Pon-A-inducible wt p53 (H1299\#23) has no effect on miR-128-2 expression, indicating that miR-128-2 is specifically regulated by mutant p53 protein. As control, miR-128-2 expression is also unchanged in $\mathrm{H} 1299$ cells transduced with the vectors of the Pon-A-inducible system (H1299-pIND; Figure 1b). miR-128-2 is accumulated in a time-dependent manner (Figure 1c). We found that the precursor of miR-128-2 (pre-miR-128-2) was also induced by mutant p53; thereby suggesting that mutant p53 could control miR-128-2 expression at the transcriptional level (Figure 1d). miR-128-2 is an intragenic miRNA located within the 18th intron of ARPP21 gene. ${ }^{30}$ The analysis of ARPP21 gene expression evidences that $A R P P 21 \mathrm{mRNA}$ is induced, to a similar extent than that of miR-128-2, following mutant p53His175 expression (Figure 1e and Supplementary Figure 1B). Altogether, these findings indicate that mutant p53 protein controls the expression of both miR-128-2 and ARPP21 through a common transcriptional regulatory mechanism.

Mutant p53 binds to and transactivates ARPP21 promoter. It has been shown that gain-of-function mutant p53 proteins acquire the ability to directly regulate gene expression by binding to the promoter of their target genes in cooperation with other transcription factors (Sp1, NF-Y, E2F1, cEts). ${ }^{12,16-18}$ We then investigated by chromatin immunoprecipitation assay the recruitment of mutant p53 to miR-128-2 regulatory regions.

As intragenic miRNAs can be either controlled by the promoter of their host gene or by their own promoter, ${ }^{31}$ we performed bioinformatic analyses searching for both promoter regions and transcription start sites (TSS) on the yet uncharacterized ARPP21 gene locus, by using Genomatix (http://www.genomatix.de) and Dragon Promoter Finder (http://mybio.wikia.com/wiki) software. A schematic representation of the identified putative promoter and TSSs, as well as the position of the primers used in chromatin immunoprecipitation (ChIP) assay, is shown in Figure 2a. We found that mutant p53 binds to three regions of the putative ARPP21 promoter (indicated as 1, 3 and 6 in Figures $2 a$ and b), whereas no mutant p53 recruitment was observed in the upstream regions of miR-128-2, located in the 18th intron of ARPP21 gene (Figure 2b).

Next, we performed transactivation assays using two different constructs of the ARPP21 promoter, one enclosing the putative TSS and one with the region upstream the first exon (Figure 2c). We observed that mutant p53 was able to transactivate the ARPP21 promoter region enclosing the putative TSS (Figure 2d). This transactivation effect was dose-dependent (Figure 2e).

Altogether, these data suggest that miR-128-2 and ARPP21 mRNA could be generated by a common precursor. This event is frequently observed for intronic miRNAs and their host genes.

miR-128-2 confers chemoresistance to lung cancer cell lines. To further investigate the contribution of miR-128-2 modulation to mutant p53 gain-of-function activity, we assessed whether miR-128-2 exogenous expression impacts on the response of two lung cancer cell lines, H1299 and A459, to doxorubicin (DOXO), cisplatinum (CDDP) and 5-fluorouracil (5-FU).

We observed that miR-128-2 expression reduces the sub-G1 cell population in both cell lines after chemotherapeutic treatments (Figure $3 a$ and $b$ and Supplementary Figure 2). Counting of Trypan blue-positive cells in the same experimental conditions confirmed that miR-128-2 expression confers chemoresistance to CDDP and DOXO in $\mathrm{H} 1299$ cells (Figure $3 \mathrm{c}$ ).

Furthermore, the analyses of the cleaved fragment of PARP (p85), a well-known substrate for caspase-3 cleavage during apoptosis, confirmed that the exogenous expression of 


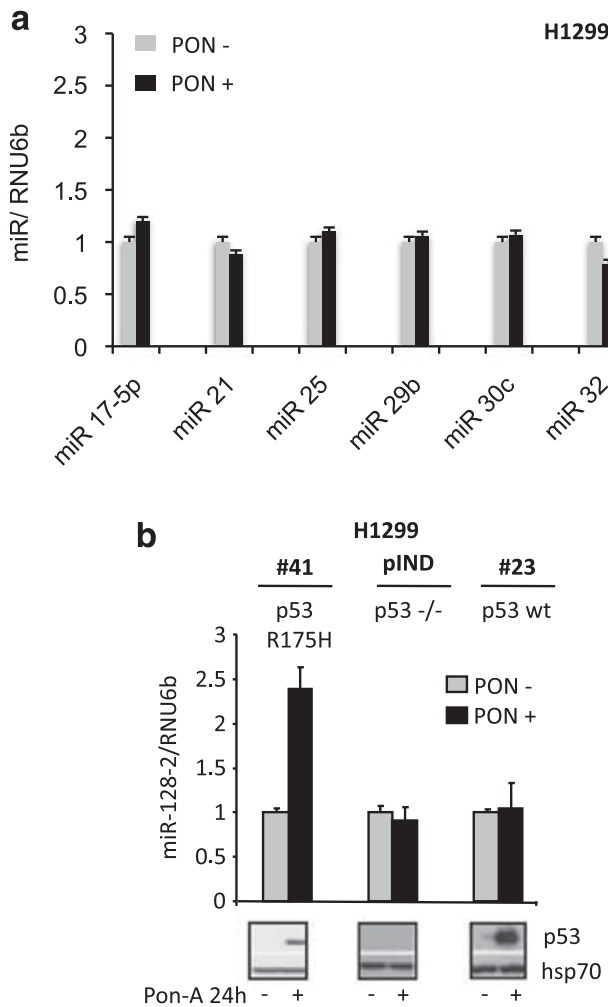

1299 \#41

d

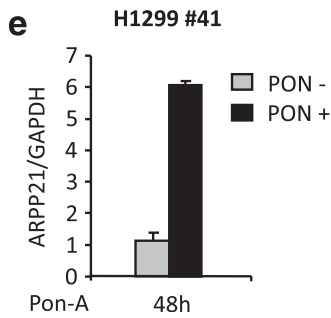

Figure 1 p53His175 transcriptionally induces the expression of miR-128-2 and of its host gene, ARPP21. (a) Quantitative RT-PCR (qRT-PCR) analysis of 11 miRNAs expression in H1299-p53His175 inducible system (H1299\#41) upon $24 \mathrm{~h}$ of ponasterone treatment. (b) qRT-PCR analysis of miR-128-2 expression on H1299\#41 (expressing inducible p53-R175H), H1299 carrying the empty vector (H1299-pIND), H1299\#23 (expressing inducible wild-type p53) cells in the presence or absence of ponasterone (24 $\mathrm{h}$ ). p53 protein induction was assessed by western blotting (below). (c) qRT-PCR analysis of miR-128-2 expression on H1299\#41 upon 24-36-48 $\mathrm{h}$ of ponasterone treatment. MicroRNAs expression levels were normalized over RNU6b expression. (d) RT-PCR analysis of pre-miR-128-2 expression in H1299-p53His175 inducible system upon $48 \mathrm{~h}$ of ponasterone treatment. (e) qRT-PCR analysis of ARPP21 expression in $\mathrm{H} 1299-\mathrm{p} 53 \mathrm{His} 175$ inducible system upon $48 \mathrm{~h}$ of ponasterone treatment

miR-128-2 reduces the apoptotic rate of both $\mathrm{H} 1299$ and $\mathrm{A} 459$ cell lines upon DOXO and 5-FU treatments (Figures $3 d$ and e). Conversely, we observed an increase of both PARP p85 and cleaved caspase 3 expression upon DOXO and cisplatin treatment in $\mathrm{H} 1299$ cells when endogenous miR-128-2 has been sequestered by the transfection of a decoy-vector, carrying tandem repeat complementary sequences of miR-128-2 (Figures $3 f$ and $g$ ). These results indicate that miR-128-2 expression confers chemoresistance to cancer cells and this effect is independent from the p53 status as occurs in both p53-null (H1299) and p53-wt (A459) cells.

miR-128-2 targets the transcriptional repressor E2F5. By using two prediction algorithms, TargetSCAN (http:// www.targetscan.org) and PicTar (http://pictar.mdc-berlin.de/), we identified the transcriptional repressor E2F5 as putative target for miR-128-2 (Figure 4a). The E2F family of transcription factors is an important class of cellular regulators that behave as both oncogenes and tumor suppressor genes in a context-specific manner. ${ }^{32}$ E2Fs can be broadly classified as activators (E2F1, E2F2, and E2F3A) or suppressors/antagonists (E2F3B, E2F4, E2F5, E2F6, E2F7, and E2F8). ${ }^{33}$ This classification refers primarily to the ability of the E2Fs to activate or inhibit transcription mediated through E2F response elements. To experimentally test whether our predicted target was regulated by miR-128-2, we analyzed E2F5 expression in H1299 cells transfected or not with miR-128-2 precursor. Because of the inability of two different antibodies to detect the endogenous E2F5 protein by western blot analysis, we analyzed its expression after immunoprecipitation-mediated enrichment. As shown in Figure $4 \mathrm{~b}$ and Supplementary Figure 3, only one of the tested antibodies (ab_1) was capable to immunoprecipitate the expected $36 \mathrm{kDa}$ form of 


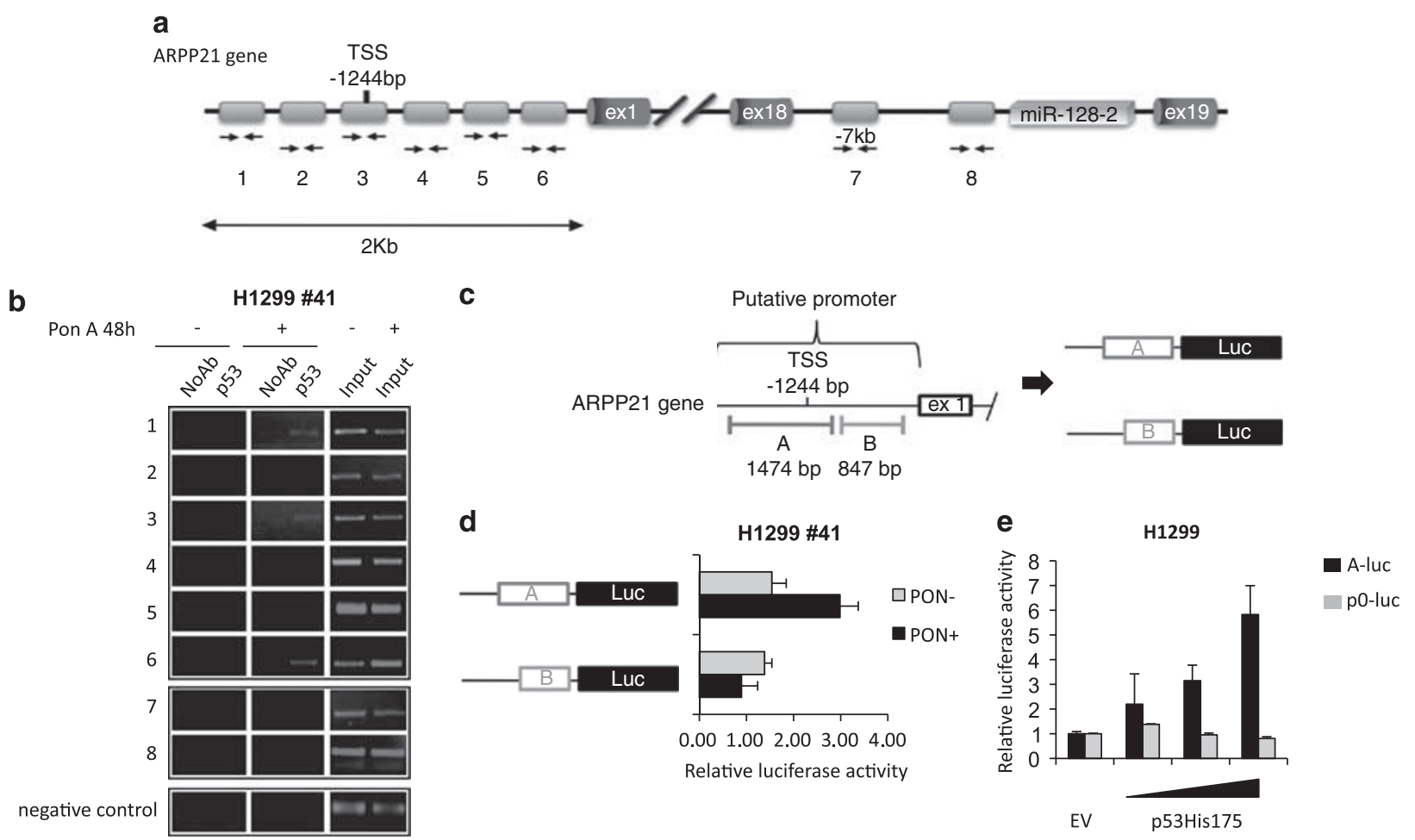

Figure 2 p53His 175 binds to and transactivates ARPP21 regulatory regions. (a) Schematic representation of $A R P P 21$ gene: three different regions have been analyzed in ChIP assays; one of $2 \mathrm{~kb}$ upstream the first exon of $A R P P 21$, for which six couples of primers that amplified adjacent regions have been drawn (1-6); one at $7 \mathrm{~kb}$ upstream miR-128-2 mature sequence in which according to Dragon Promoter Finders software analysis a putative TSS is present (indicated as 7); one upstream the $5^{\prime}$ of mir-128-2 mature sequence (indicated as 8). (b) Cross-linked chromatin from proliferating H1299-p53His175 inducible cells, untreated or treated with ponasterone for $48 \mathrm{~h}$, was immunoprecipitated with an antibody (Ab) to p53 or in the absence of antibody, and analyzed by PCR with primers specific for the indicated regions (see Materials and Methods). Input, non-immunoprecipitated cross-linked chromatin. (c) Schematic representation of the plasmids used in the luciferase experiments (d and e). (d) H1299p53His 175 inducible cells were transiently transfected with two constructs carrying the luciferase reporter gene driven by two adjacent regions of ARPP21 promoter; one enclosing the putative TSS (A-luc) and one enclosing the upstream region of first exon (B-luc) and treated for 24 or $48 \mathrm{~h}$ with ponasterone. (e) $\mathrm{H} 1299$ cells were transiently transfected with A-luc construct and increasing amounts of pcDNA3 vector containing p53His175 cDNA. An equal amount of CMV- $\beta$-gal was added to each transfection mixture. Cell extracts were prepared $48 \mathrm{~h}$ later and subjected to determination of luciferase activity. Results are presented as luciferase activity (Luc) relative to total proteins and $\beta$-galactosidase $(\beta$-gal) activity. Histograms show the mean of three experiments performed in duplicate

E2F5 (Figure 4b and Supplementary Figure 3, control samples). miR-128-2 exogenous expression strongly reduced the amount of the immunoprecipitated E2F5 protein in H1299 cells (Figure 4b). This reduction was also observed when E2F5 protein staining was analyzed by immunocytochemistry (Figure $4 \mathrm{c}$ and Supplementary Figure 4, panel A). To formally demonstrate that miR-128-2 targets E2F5 mRNA, the E2F5-3'-UTR was cloned downstream the Renilla luciferase gene in the $\mathrm{pRL}-\mathrm{TK}$ vector (pRL-TK-E2F5$3^{\prime}-$ UTR). As shown in Figure $4 \mathrm{~d}$ miR-128-2 transfection significantly decreased the Renilla luciferase activity of the vector enclosing E2F5-3'-UTR.

As in the cells transfected with miR-128-2, we also observed a reduction of E2F5 protein level in $\mathrm{H} 1299 \# 41$ cells following mutant p53His175 induction (Figure 4e). E2F5 protein decrease after mutant p53 expression was also assessed by immunocytochemistry in the same experimental conditions (Supplementary Figure 4b).

miR-128-2 induces p21 ${ }^{\text {waf1 }}$ expression and cytoplasmic localization in lung cancer cell lines. It is well established that sensitivity to chemotherapeutic treatments is strongly linked to cell cycle regulation. When the effect of miR-128-2 exogenous expression on cell cycle regulatory proteins was evaluated we found that p21 1 waf1 expression is induced by miR-128-2 in H1299 (p53-null) and A459 (p53-wt) cells at both mRNA and protein levels (Figures $5 a$ and b). p21 wat1 induction also occurs in $\mathrm{H} 1299 \# 41$ after induction of $\mathrm{mp} 53 \mathrm{His} 175$ protein that upregulates miR-128-2 expression (Figures $5 a, b$ and $1 b$ ). The observed induction of p21 $1^{\text {waf1 }}$ in A459 cells seems not to be mediated by endogenous wt p53, as no p53 protein stabilization was observed after miR-128-2 exogenous expression (Supplementary Figure 5). These observations indicate that miR-128-2-dependent p21 induction, as the above-described miR-128-2-mediated chemoresistance, is independent of p53 status.

By using the Matlnspector software (http://www.genomatix. de/en/index.html), we identified the presence of binding sites for the E2F family of transcription factors on $\mathrm{p} 21^{\text {waf1 }}$ promoter. To evaluate whether the transcriptional repressor E2F5 binds to p21 ${ }^{\text {waf1 }}$ promoter, we performed ChIP experiments. We observed that E2F5 binds to p21 ${ }^{\text {waf1 }}$ promoter in $\mathrm{H} 1299$ cells (Figure 5c, left). Exogenous expression of miR-128-2 releases E2F5 occupancy of p2 $1^{\text {waf1 }}$ promoter (Figure 5c, right). This pairs with the decrease of E2F5 protein levels in the same experimental condition (shown in Figure $4 b$ and $c$ ) 


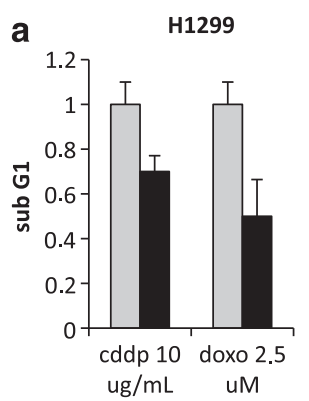

$\square$ control

miR-128-2
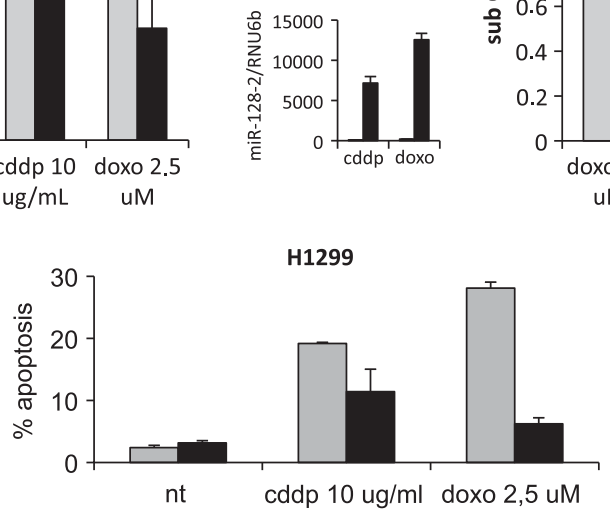

b

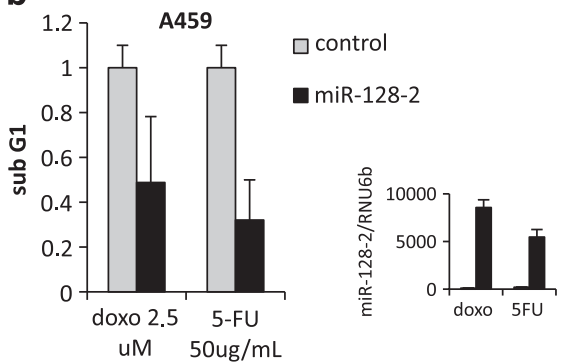

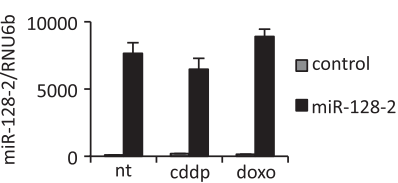

\begin{tabular}{|l|c|c|c|}
\hline control & $2.40 \pm 0.4$ & $19.18 \pm 0.2$ & $28.10 \pm 0.9$ \\
\hline miR $-128-2$ & $3.16 \pm 1$ & $11.42 \pm 4$ & $6.23 \pm 2$ \\
\hline
\end{tabular}
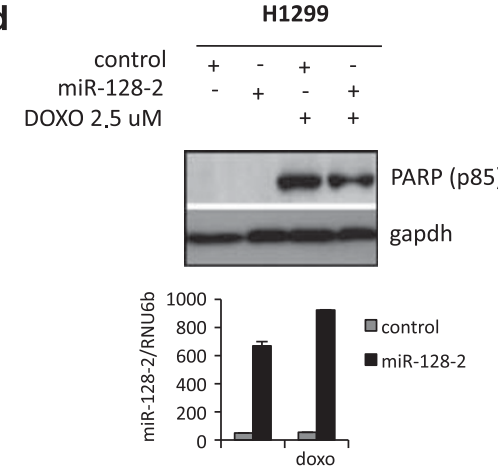

$\mathbf{f}$

decoy control decoy miR-128-2 DOXO 2.5 uM
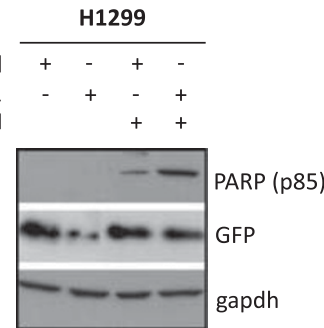

e
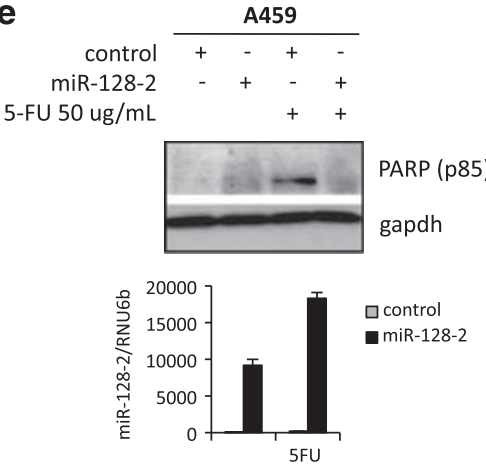

g

decoy control decoy miR-128-2 CDDP $10 \mathrm{ug} / \mathrm{mL}$

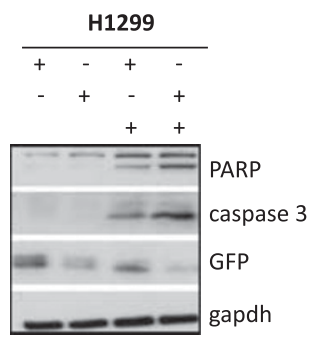

Figure 3 miR-128-2 confers chemoresistance to lung cancer cell lines. (a and $\mathbf{b})$ Percentage of cells in sub-G1 phase obtained by FACS analysis performed in H1299 and A459 cells after $48 \mathrm{~h}$ of transfection with $5 \mathrm{nM}$ miR-128-2 mimic or control mimic, and $24 \mathrm{~h}$ of treatment with $2,5 \mu \mathrm{M}$ doxorubicin (DOXO), 5 and $10 \mu \mathrm{g} / \mathrm{ml}$ cisplatinum (CDDP), and $50 \mu \mathrm{g} / \mathrm{ml} 5$-fluorouracil (5-FU). Histograms show the mean of three experiments performed in duplicate. Mir-128-2 relative expression levels were evaluated by qRT-PCR (right graph). (c) Cell killing was measured by Trypan blue assay $48 \mathrm{~h}$ after transfection with $5 \mathrm{nM} \mathrm{miR}-128-2$ mimic or control mimic in $\mathrm{H} 1299$ treated for $24 \mathrm{~h}$ with $10 \mu \mathrm{g} / \mathrm{ml}$ $\mathrm{CDDP}$ and 2,5 $\mu \mathrm{M}$ DOXO. Data are shown as means \pm S.D. of triplicate counts. Mir-128-2 relative expression levels were evaluated by qRT-PCR (right graph). (d and $\mathbf{e}$ ) Cleavage of the caspase substrate PARP in $\mathrm{H} 1299$ and A459 cells transfected with miR-128-2 mimic or control mimic and treated for $24 \mathrm{~h}$ with $2.5 \mu \mathrm{M} \mathrm{DOXO}$ and $50 \mu \mathrm{g} / \mathrm{ml}$ 5FU, respectively. Mir-128-2 relative expression levels were evaluated by qRT-PCR (low graphs). (f and g) Cleavage of the caspase substrate PARP in H1299 cells transiently transfected with decoy-miR-128-2 or decoy-control vectors and treated for $24 \mathrm{~h}$ with $2.5 \mu \mathrm{M} \mathrm{DOXO}$ and $10 \mu \mathrm{g} / \mathrm{ml} \mathrm{CDDP}$. The amounts of cleaved caspase-3 were analyzed by western blot using a specific antibody to caspase-3. MiR-128-2 sequestration was controlled by western blot analysis of GFP protein expression

and indicates that E2F5 is involved in the transcriptional modulation of p21 observed after miR-128-2 overexpression.

In agreement with a role for miR-128-2 in the control of p21 expression, the transfection of a specific decoy for miR-128-2 in p53His175-inducible $\mathrm{H} 1299$ cells prevents p21 ${ }^{\text {waf1 }}$ protein accumulation (Figure $5 \mathrm{~d}$ ). The analysis of $\mathrm{p} 21^{\text {waf1 }}$ protein half-life revealed that the protein is more stable upon miR-128-2 exogenous expression (Figure 5e). Within the same experimental conditions, we found that the half-life of cyclin D1, a protein involved in the promotion of $\mathrm{p} 21^{\text {waf1 }}$ stability, ${ }^{34}$ was also extended, thereby suggesting that miR128-2 promotes both the induction of $\mathrm{p} 21^{\text {waf1 }}$ transcript as well as the maintenance of $\mathrm{p} 21^{\text {waf } 1}$ protein stability. 
a b

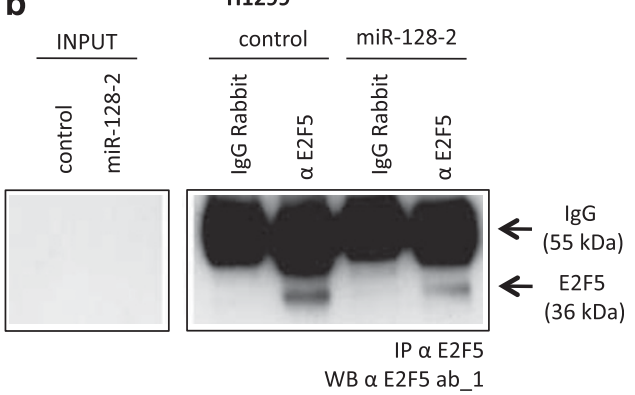

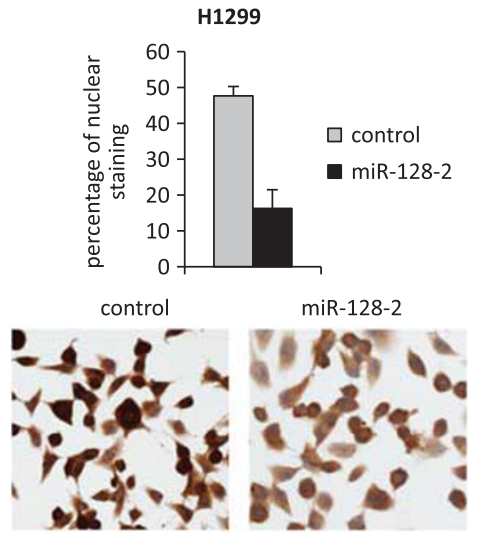

d
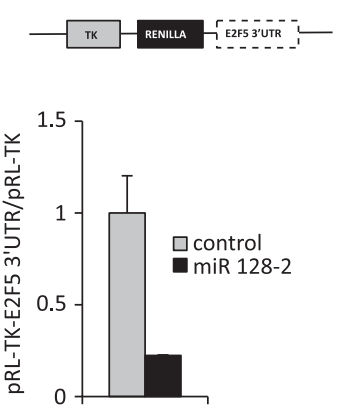

e

H1299 \#41

f
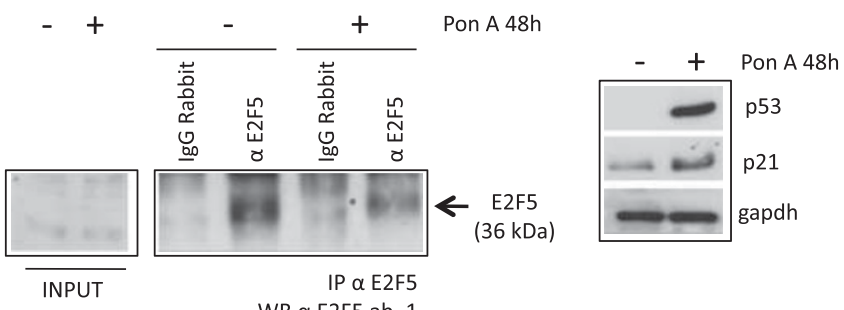

WB $\alpha$ E2F5 ab 1

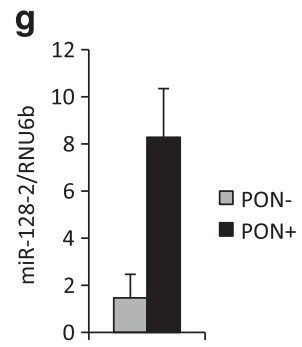

Figure 4 mir-128-2 targets the transcriptional repressor E2F-5. (a) Predicted duplex formation between human E2F5-3'-UTR and miR-128-2. (b) Western blot analysis of E2F5 protein levels after immunoprecipitation-mediated enrichment in $\mathrm{H} 1299$ cells transfected with $5 \mathrm{nM}$ of miR-128-2 mimic or control mimic for $48 \mathrm{~h}$. E2F5 protein was evidenced by using E-19 antibody from Santa Cruz Biotechnology. (c) Analysis of E2F5 protein expression by immunocytochemistry in H1299 cells transfected with $5 \mathrm{nM}$ of miR-128-2 mimic or control mimic was performed using anti-E2F5 antibody from Santa Cruz Biotechnology (E-19). The graph (left panel) shows the percentage of E2F5positive nuclei. The right panel shows a representative image of E2F5 protein staining. (d) Renilla luciferase activity of E2F5-3'-UTR reporter gene in H1299 cells transiently transfected with $5 \mathrm{nM}$ of miR-128-2 mimic or control mimic. An equal amount of pGL3-basic firefly luciferase reporter vector was added to each transfection mixture. Cell extracts were prepared $48 \mathrm{~h}$ later and subjected to determination of Renilla and firefly luciferase activities. Results are presented as Renilla activity relative to total proteins and firefly activity. Histograms show the mean of three experiments performed in duplicate. (e) Western blot analysis of E2F5 protein levels after immunoprecipitation-mediated enrichment in H1299-p53His 175 inducible cells upon $48 \mathrm{~h}$ of ponasterone treatment. E2F5 protein was evidenced by using E-19 antibody from Santa Cruz Biotechnology. (f) p53 and p2 $1^{\text {wat1 }}$ proteins levels in H1299-p53His175 inducible cells upon $48 \mathrm{~h}$ of ponasterone treatment. (g) Mir-128-2 relative expression levels were evaluated by qRT-PCR

p2 $1^{\text {waf1 }}$ has been shown to exert dual and opposite effects, depending on its subcellular localization. Indeed, p21waf1 nuclear localization promotes growth arrest, while its cytoplasmic accumulation prevents apoptosis through the interaction and the suppression of pro-caspase-3. ${ }^{35}$ Because of these opposite roles of $\mathrm{p} 21^{\text {waf1 }}$ depending on its subcellular localization and to the observed miR-128-2-dependent antiapoptotic effect, we analyzed p21 waf1 subcellular localization upon miR-128-2 overexpression. We observed, by cell fractionation (Figure 5f) and immunofluorescence (Figure $5 \mathrm{~g}$ ), that p21 waf1 accumulates in the cytoplasm of both $\mathrm{H} 1299$ and A459 cell lines following miR-128-2 exogenous expression. We therefore analyzed p21 $1^{\text {waf1 }}$ and caspase-3 subcellular localization after miR-128-2 expression. As shown in Figure 6a, we observed that p2 $1^{\text {waf1 }}$ and pro-caspase-3 colocalize in the cytoplasm, thereby suggesting the involvement of $p 21^{\text {waf1 }}$ in the inhibition of pro-caspase-3 cleavage following miR-128-2 exogenous expression. We found that exogenous expression of miR-128-2 reduces pro-caspase-3 cleavage in both $\mathrm{H} 1299$ and $\mathrm{A} 459$ cell lines upon CDDP (left) and 5-FU (right) treatment, respectively (Figure $6 \mathrm{~b}$ ). We also found that mutant p53 expression, which leads to p21 waf1 induction, markedly reduces DOXO-induced PARP cleavage (Figure 6c, left). On the contrary, exogenous expression of a specific decoy for miR-128-2 impairs $\mathrm{p} 21^{\text {waf1 } 1}$ protein induction and renders mutant p53-expressing cancer cells less prone to the killing by DOXO (Figure 6c, right). 
a

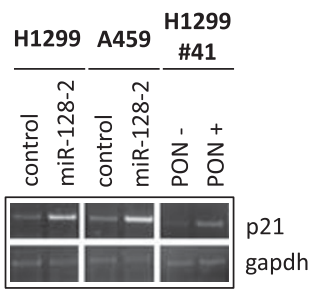

C

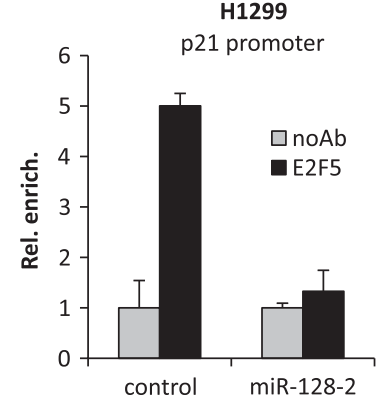

b

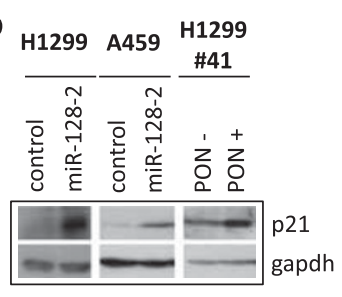

d

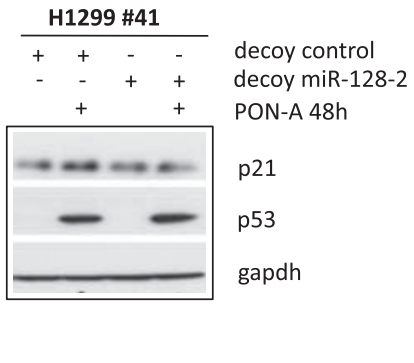

e

H1299

\begin{tabular}{|c|c|c|c|c|c|c|c|c|c|c|c|}
\hline \multicolumn{6}{|c|}{ control } & \multicolumn{6}{|c|}{ miR-128-2 } \\
\hline 0 & 15 & 30 & 60 & 120 & 960 & 0 & 15 & 30 & 60 & 120 & 960 \\
\hline$m$ & - & - & - & - & & & & & & - & \\
\hline$\infty$ & - & $=6$ & & & & 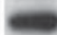 & $=$ & - & - & & \\
\hline- & - & - & - & - & & - & & & & & 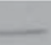 \\
\hline
\end{tabular}

$\mathrm{CHX} 20 \mathrm{ug} / \mathrm{mL}$ (min)

p21

cyclin D1

gapdh

\section{9}

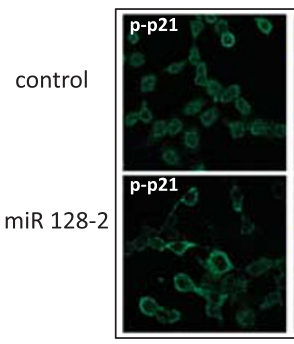

A459

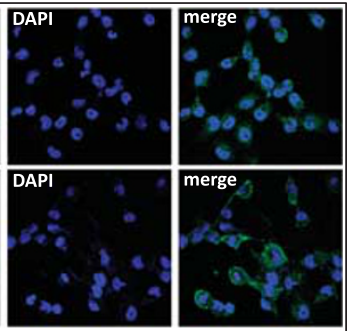

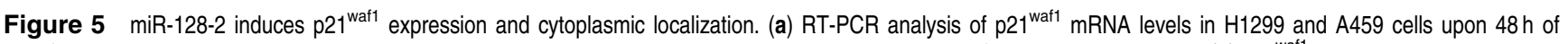
transfection with $5 \mathrm{nM}$ miR-128-2 mimic or control mimic and in H1299-p53His175 inducible cells upon $48 \mathrm{~h}$ of ponasterone treatment. (b) p21 waf1 protein levels in H1299 and A459 cells after $48 \mathrm{~h}$ of miR-128-2 expression and in H1299-p53His 175 inducible cells upon $48 \mathrm{~h}$ of ponasterone treatment. (c) Cross-linked chromatin from $\mathrm{H} 1299 \mathrm{cells}$ after $48 \mathrm{~h}$ of transfection with $5 \mathrm{nM}$ miR-128-2 mimic or control mimic was immunoprecipitated with antibody (Ab) to E2F5 or in the absence of antibody, and analyzed by PCR with primers specific for the region of $\mathrm{p} 21^{\text {waf1 }}$ promoter enclosing the E2F binding site. (d) p21 waf1 protein levels in $\mathrm{H} 1299$-p53His 175 inducible cells transiently transfected with decoy-miR-128-2 or decoy-control vectors and treated for $48 \mathrm{~h}$ with ponasterone. (e) Analysis of p21 waf1 and cyclin D1 proteins stability in $\mathrm{H} 1299 \mathrm{cells}$ transfected for $48 \mathrm{~h}$ with $5 \mathrm{nM}$ miR-128-2 mimic or control mimic and treated with $20 \mu \mathrm{g} / \mathrm{ml}$ cycloheximide (CHX) to inhibit new protein synthesis for the times indicated. Protein levels of p21 waf1 , cyclin D1 and glyceraldehyde 3-phosphate dehydrogenase (gapdh) were analyzed by immunoblot. (f) Cellular localization of p21 waf1 determined by cellular fractionation in $\mathrm{H} 1299$ and A459 cells transfected for $48 \mathrm{~h}$ with $5 \mathrm{nM}$ miR-128-2 mimic or control mimic. Equal amounts $(40 \mu \mathrm{g})$ of cytoplasmic fraction and nuclear fractions from each sample were analyzed by $12 \%$ SDS-PAGE. Gapdh and Histone $\mathrm{H} 1$ were used as markers of the cytoplasmic and nuclear fraction, respectively. (g) Subcellular localization of endogenous p21 waf1 in A459 cells transiently transfected for $48 \mathrm{~h}$ with $5 \mathrm{nM}$ miR-128-2 mimic or control mimic visualized by immunofluorescence using anti-p-p21 antibodies. DNA staining with DAPI and a merged view of green and blue channels of the same field is shown (merge)

Altogether these findings highlight $\mathrm{p} 21^{\text {waf1 }}$ protein as a mediator of miRNA-128-2-induced chemoresistance.

\section{Discussion}

In the present study, we explored the possibility that mutant p53 proteins exert gain-of-function activity through the modulation of miRNA expression in NSCLC cells. miRNAs are important players in tumorigenesis and a differential expression of specific signatures of miRNAs in the tumor tissues compared with their normal counterparts has emerged in almost all cancer types so far analyzed, including lung. ${ }^{28,29}$ We evidenced that mutant $\mathrm{p} 53 \mathrm{R} 175 \mathrm{H}$ is able to induce the expression of miR-128-2 by transactivating the promoter 
a
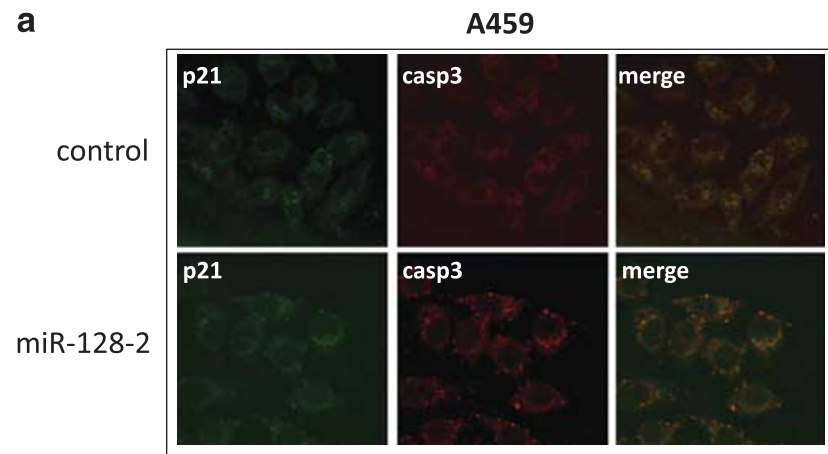

b
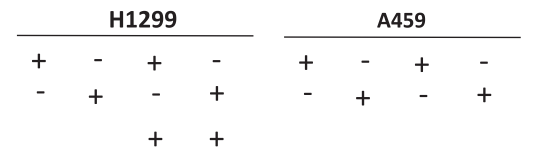

control

miR-128-2

$+\quad+$

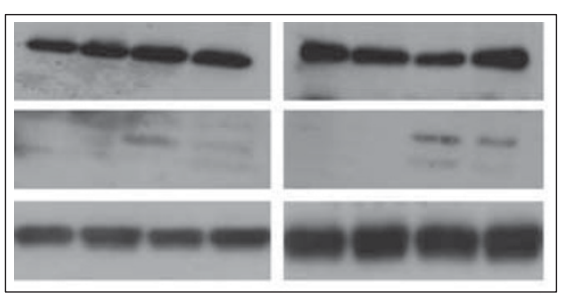

CDDP $10 \mathrm{ug} / \mathrm{mL}$

5FU 50uM

pro caspase 3

caspase 3

tubulin

C

H1299 \#41

\begin{tabular}{|c|c|c|c|c|}
\hline \multirow[b]{2}{*}{ PON-A 48h } & \multicolumn{2}{|c|}{ decoy control } & \multicolumn{2}{|c|}{ decoy miR-128- } \\
\hline & + & + & + & + \\
\hline $2,5 \mathrm{uM}$ & & + & & + \\
\hline
\end{tabular}

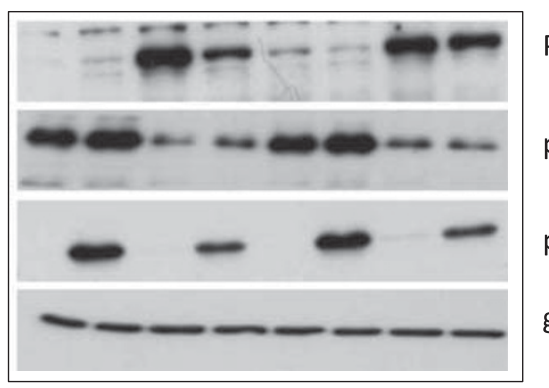

$\operatorname{PARP}(p 85)$

p21

p53

gapdh

Figure 6 miR-128-2-induced cytoplasmic p2 $1^{\text {waf1 }}$ promotes chemoresistance. (a) Colocalization of p21 waf1 and caspase-3 in A459 cells transfected for $48 \mathrm{~h}$ with miR-128-2 mimic or control mimic stained with anti-p21 (green) and anticaspase-3 (red) antibodies. A merged view of green and red channels of the same field is shown (merge). (b) Amounts of cleaved caspase-3 analyzed by western blot using a specific antibody to caspase-3 and full-length pro-caspase-3 in $\mathrm{H} 1299$ and A459 cells transiently transfected for $48 \mathrm{~h}$ with $5 \mathrm{nM}$ miR-128-2 mimic or control mimic and treated for $24 \mathrm{~h}$ with $10 \mu \mathrm{g} / \mathrm{ml}$ cisplatinum (CDDP) and $50 \mu \mathrm{M}$ 5-fluorouracil (5-FU), respectively. (c) H1299-p53His175 inducible cells were transiently transfected with decoy-miR-128-2 or decoy-control vectors and then induced for $48 \mathrm{~h}$ with ponasterone and treated for $24 \mathrm{~h}$ with $2.5 \mu \mathrm{M} \mathrm{DOXO}$. Amounts of cleaved PARP fragment (p85), p21 ${ }^{\text {waf1 }}$, p53 and gapdh proteins were analyzed by immunoblot

of its host gene, ARPP21. The transcriptional induction of miR-128-2 by mutant $\mathrm{p} 53 \mathrm{R} 175 \mathrm{H}$ results in the increased chemoresistance of cancer cells.

Additional miRNAs have been previously shown to modulate sensitivity to chemotherapeutic treatments. The cluster

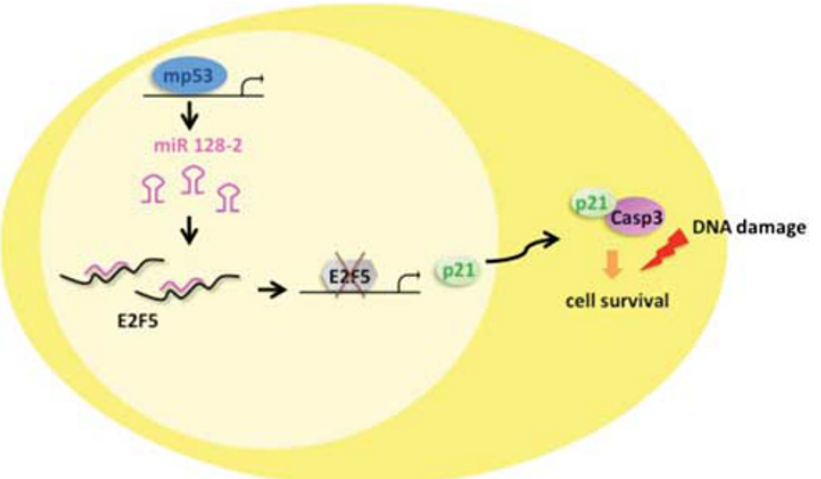

Figure 7 Schematic representation of the proposed molecular mechanism. Mutant p53 protein is able to induce miR-128-2 expression that in turn determines p21 $1^{\text {waf1 }}$ upregulation, in part by inhibiting E2F5 transcriptional repressor activity on p21 ${ }^{\text {waf1 }}$ promoter, and its localization in the cytoplasm where it exerts its antiapoptotic function by binding to pro-caspase-3

comprising miR-183/miR-96/miR-182 for example is upregulated in cells characterized by multidrug resistance. ${ }^{36}$ miR-182 was also shown to target BRCA1 impeding DNA repair in breast cancer cells. ${ }^{37}$ In lung cancer, a crucial role in chemoresistance is played by miR-630, which is responsible for the blocking of p53 activation and cleavage of caspases in response to cisplatin treatment. ${ }^{38}$

It is well established that cancer cells carrying endogenous conformational p53 mutant proteins are less sensitive to chemotherapeutic treatments compared with cells carrying p53 gene deletions. By exogenous expression or decoymediated depletion of miR-128-2 we could assess that miR-128-2 is able to confer resistance to different chemotherapeutic agents, such as 5-FU and DOXO, independently from the presence of mutant p53. Mutant p53 then seems to be involved in the transactivation of a miRNA that per se confers resistance to chemotherapeutic agents. As the miR-128-2 confers chemoresistance it is reasonable to speculate that many additional oncogenic stimuli, other than p53 mutation, could lead to miR-128-2 induction during lung tumorigenesis (Figure 7).

Importantly, miR-128-2 expression causes p21 ${ }^{\text {waf1 }}$ upregulation and accumulation in the cytoplasm, a feature that was repeatedly associated with an anti-apoptotic effect of $p 21^{\text {waf1 }}$. p $21^{\text {waf1 } 1}$ induction occurs as a result of the translational inhibition of the transcriptional repressor E2F5 by miR-128-2. E2F5-3'-UTR is indeed directly controlled by miR-128-2 and the decrease of E2F5 protein level after miR-128-2 expression leads to its detachment from $\mathrm{p} 21^{\text {waf } 1}$ promoter and to the increase of p2 $1^{\text {waf1 }} \mathrm{mRNA}$ and protein levels (Figure 7).

Several studies have pointed out that, in addition to being an inhibitor of cell proliferation, p2 $1^{\text {waf1 }}$ acts as an inhibitor of apoptosis in a number of systems; indeed p21 ${ }^{\text {waf1 }}$ phosphorylation frequently pairs with its cytoplasmic localization and anti-apoptotic function, as observed in different tumor types, and correlates with an increased chemoresistance. ${ }^{39-41}$ Indeed, Akt phosphorylation at threonine 145 induces p2 $1^{\text {waf } 1}$ cytoplasmic localization and its subsequent binding to pro-caspase-3 that prevents pro-casapase-3 cleavage and 
blocks the apoptotic response. ${ }^{33}$ In agreement with these evidences, we observed that miR-128-2-induced $\mathrm{p} 21^{\text {waf1 }}$ protein is localized in the cytoplasm, where it binds to procaspase-3. The molecular mechanism responsible for $\mathrm{p} 21^{\text {waf } 1}$ protein cytoplasmic localization following miR-128-2 expression needs to be identified yet. It is reasonable to assume that miR-128-2 modulates the expression and activation of additional proteins involved in the control of p21 waf1 subcellular localization. In addition to the cytoplasmic translocation and increase in the stability of p21 $1^{\text {waf1 }}$, we observed an increased half-life of cyclin D1. This led us to speculate that the PI3K/Akt pathway is likely involved in response to miR-128-2. It was indeed shown that PI3K/Akt activation results in the inhibition of GSK3 $\beta$ kinase, the major responsible of cyclin D1 phosphorylation and subsequent degradation. Activation of PI3K/Akt signaling then may lead to the stabilization of cyclin D1, which could in turn participate to $\mathrm{p} 21^{\text {waf1 }}$ protein stabilization after miR-128-2 expression. As mentioned above, Akt activation has been also shown to phosphorylate p21 $1^{\text {waf1 }}$, leading to its cytoplasmic localization.

We provide evidence that miR-128-2 induction contributes to the well-established chemoresistance activity mediated by mutant p53. Of relevance, mutant p53-driven chemoresistance is counteracted by the repressive function of E2F5. Taken together, these findings with those showing that mutant cooperates with E2F1 in the promotion of neoangiogenesis, ${ }^{12}$ highlight a close link between gain-of-function mutant p53 proteins and E2F family members.

As mentioned above, mutant $\mathrm{p} 53 \mathrm{R} 175 \mathrm{H}$ expression leads to the induction of both miR-128-2 and ARPP21 expression. By using a chromatin immunoprecipitation approach, we observed that mutant $\mathrm{p} 53$ binds three different regions of the putative promoter region of ARPP21 gene. Mutant p53 has been repeatedly reported to function as an oncogenic transcription factor. ${ }^{42,43}$ Mutant p53 proteins can indeed be recruited in large transcriptional complexes enabling their recruitment to the promoters of cancer-related target genes, such as Fas/CD91, Egr1, Cdk1 and cyclin B2, Id2, Id4, TGF $\beta 1$, HIRA and many others. Our study provides the first evidence of the ability of the transcriptional complexes containing mutant p53 to modulate the expression of a miRNA. Several transcription factors can cooperate with mutant p53 in transcription (e.g., NF-Y, NF- $\kappa \mathrm{B}, \mathrm{E} 2 \mathrm{~F} 1, \mathrm{VDR})$ and many of their binding sites are present on ARPP21 promoter. The mutant p53-containing transcriptional complexes recruited on $A R P P 21$ promoter deserve further investigation.

As each miRNA controls the expression of a plethora of target mRNAs, the identification of miRNAs targeted by mutant p53 opens new opportunities to develop molecular tools aimed at interfering with mutant p53 oncogenic function.

\footnotetext{
Materials and Methods

Cell cultures and treatments. $\mathrm{H} 1299, \mathrm{H} 1299$ clone $41, \mathrm{H} 1299$ clone 23 and H1299 clone pIND cells were cultured and induced as previously reported. ${ }^{12,20}$ Human epithelial non-small-cell lung adenocarcinoma A459 cells were cultured in DMEM medium (Invitrogen, Carlsbad, CA, USA) with $10 \%$ (v/v) FCS. For chemoresistance experiments, cells were treated with CDDP (Pfizer, New York, NY, USA), DOXO (Ebewe Pharma, Kundl, Austria) and 5-FU (Teva, Petach Tikva, Israel) at the indicated concentrations for $24 \mathrm{~h}$. For protein stability assays, cells
}

were treated with $20 \mu \mathrm{g} / \mathrm{ml}$ cycloheximide (Sigma-Aldrich, St. Louis, MO, USA) at the indicated times.

Plasmids and transfections. Reporter vector A-Luc and B-Luc were generated by cloning $1474 \mathrm{bp}$ and $847 \mathrm{bp}$, respectively, from the ARPP21 promoter in the BamHI site of Po-LUC vector. Mutant p53 exogenous expression was performed using pcDNA3-p53-R175H vector. Reporter vector pRL-TK-E2F5-3'UTR was generated by cloning $653 \mathrm{bp}$ from the E2F5-3'-UTR region in the Xbal site of HSV-pRL-TK (Promega, Madison, WI, USA). Primers used for the amplifications are listed in Supplementary Table 1.

miR-128-2 activity was abrogated using a lentiviral vector named TWEEN $3^{\prime}$-UTR (TW3), enclosing a multicloning site in the $3^{\prime}$-UTR of an EGFP reporter gene, where we inserted two antisense sequences for miR-128-2 (decoy-miR-128-2 vector). For mature miR-128-2 expression, we used $5 \mathrm{mM}$ miRNA Mimics (Dharmacon, Lafayette, CO, USA): hsa-miR-128-2-mimic and negative control \#1. H1299 and A459 cells were transfected with Lipofectamine 2000 following the manufacturer's instructions (Invitrogen).

Cells extracts and western blot. Cells were lysed in hypotonic lysis buffer (10 mM Tris pH 8; $120 \mathrm{mM} \mathrm{NaCl;} 15 \%$ glycerol; 0.5\% Nonidet P-40; fresh DTT $2.5 \mathrm{mM}$. and fresh protease inhibitors). Extracts were sonicated for $20 \mathrm{~s}$ and centrifuged at $14000 \times$ r.p.m. for $15 \mathrm{~min}$ to remove cell debris. Protein concentrations were determined by colorimetric assay (Bio-Rad, Hercules, CA, USA). Western blotting was performed using the following primary antibodies: mouse monoclonal anti-GAPDH (Santa Cruz Biotechnology, Santa Cruz, CA, USA); mouse monoclonal anti-tubulin (Santa Cruz Biotechnology); mouse monoclonal anti-hsp-70 (Santa Cruz Biotechnology); goat polyclonal anti-histone-H1 (Santa Cruz Biotechnology); mouse monoclonal anti-p53 (DO1); rabbit polyclonal anti-E2F5 (Santa Cruz Biotechnology, E-19); rabbit polyclonal anti-E2F5 (Abgent, San Diego, CA, USA); rabbit polyclonal anti-p21 (Santa Cruz Biotechnology); rabbit polyclonal anti-PARP (Cell Signaling, Danvers, MA, USA); mouse monoclonal anti-caspase-3 (Alexis, San Diego, CA, USA); mouse monoclonal anti-cyclin D1 (Invitrogen). Secondary antibodies used were goat anti-mouse, goat anti-rabbit and rabbit anti-goat, conjugated to horseradish peroxidase (Amersham Biosciences, Piscataway, NJ, USA). Immunostained bands were detected by chemiluminescent method (Pierce, Rockford, IL, USA).

Nucleocytoplasmic extracts preparation. After pelleting and removal of D-PBS, cells were allowed to swell for $10 \mathrm{~min}$ on ice in a hypotonic buffer (10 mM HEPES-KOH pH 7.9; $1.5 \mathrm{mM} \mathrm{MgCl} ; 10 \mathrm{mM} \mathrm{KCl} ; 0.5 \mathrm{mM}$ dithiothreitol; $0.2 \mathrm{mM}$ phenylmethylsulfonyl fluoride) followed by vortexing and centrifugation. The supernatants were removed and used as cytosolic fraction and the pellet (corresponding to the nuclei) was resuspended in a high salt buffer (20 mM HEPES$\mathrm{KOH}$ pH 7.9; $25 \%$ glycerol; $0.42 \mathrm{M} \mathrm{NaCl} ; 1.5 \mathrm{mM} \mathrm{MgCl}_{2} ; 0.2 \mathrm{mM}$ EDTA; $0.5 \mathrm{mM}$ dithiothreitol; $0.2 \mathrm{mM}$ phenylmethylsulfonyl fluoride) for $30 \mathrm{~min}$ to extract nuclear proteins.

Immunoprecipitation. Cells were lysed in lysis buffer $(50 \mathrm{mM}$ Tris- $\mathrm{HCl} \mathrm{pH}$ 7.5; $150 \mathrm{mM} \mathrm{NaCl} ; 5 \mathrm{mM}$ EDTA; $10 \mathrm{mM} \mathrm{MgCl} 2 ; 1 \mathrm{mM} \mathrm{KCl} ; 0.5 \%$ NP40). For each immunoprecipitation, $1 \mu \mathrm{g}$ of rabbit $\alpha \mathrm{E} 2 \mathrm{~F} 5$ antibody (Santa Cruz Biotechnology, $\mathrm{E}-19)$ and $1 \mu \mathrm{g}$ of rabbit $\operatorname{lgG}$ as control were used. Precleared extracts were incubated with protein A/G-Agarose beads (Pierce) in lysis buffer containing $0.05 \%$ $\mathrm{BSA}$ and antibodies, under constant shaking at $4^{\circ} \mathrm{C}$ over night. After incubation, agarose bead-bound immunocomplexes were rinsed with lysis buffer and eluted in $50 \mu \mathrm{l}$ of SDS sample buffer for western blotting.

RNA extraction and reverse transcriptase reaction. Cells were harvested in TRIzol reagent (Invitrogen) and total RNA was isolated as per the manufacturer's instructions. Five micrograms of total RNA were reverse-transcribed at $37^{\circ} \mathrm{C}$ for $60 \mathrm{~min}$ in the presence of random hexamers and Moloney murine leukemia virus reverse transcriptase (Invitrogen). PCR analyses were carried out by using oligonucleotides specific for the genes listed in Supplementary Table 2. ARPP21 and GAPDH expressions were measured by real-time PCR using the Sybr Green assay (Applied Biosystems, Carlsbad, CA, USA) on a StepOne instrument (Applied Biosystems). RTq-PCR quantification of miRNA expression was performed using TaqMan MicroRNA Assays (Applied Biosystems) according to the manufacturer's protocol. RNU6B, RNU19, RNU44, RNU49 and RNU66 were used as endogenous controls to standardize miRNA expression. All reactions were performed in duplicate. Taqman probes for the following miRNAs were purchased 
from Applied Biosystems: hsa-miR-17-5p, hsa-miR-21, hsa-miR-25, hsa-miR-29b, hsa-miR-30c, hsa-miR-32, hsa-miR-107, hsa-miR-128-2, hsa-miR-155, hsa-miR199a, hsa-miR-221.

Luciferase assays. Assay in H1299-p53His175 inducible cells: cells were co-transfected in a 60 -mm plate with $500 \mathrm{ng}$ of ARPP21-promoter-A-luc or ARPP21promoter-B-luc reporter constructs and treated with Pon-A for 24 or $48 \mathrm{~h}$. Assay in H1299 cells were co-transfected in a 60-mm plate with $500 \mathrm{ng}$ of ARPP21-promoterA-luc or ARPP21-promoter-B-luc reporter constructs together with increasing amounts of $\mathrm{pCDNA}_{3}$-p53His175 (750 ng to $3 \mu \mathrm{g}$ ). For normalization of transfection efficiency, $500 \mathrm{ng}$ of pRL-TK reporter (Promega), constitutively expressing the Renilla luciferase, was included. After $48 \mathrm{~h}$, cells were lysed and assayed for luciferase activity using the Dual Luciferase kit (Promega) to measure both Renilla and firefly luciferase activities. 3'-UTR reporter assays: H1299 cells were co-transfected in a $60-\mathrm{mm}$ plate with $500 \mathrm{ng}$ of pRL-TK-E2F5-3'-UTR or pRL-TK (as control) constructs together with $5 \mathrm{nM}$ miR-128-2 mimic or control mimic. An equal amount of pGL3-basic firefly luciferase reporter vector was added to each transfection mixture. Cell extracts were prepared $48 \mathrm{~h}$ later and subjected to determination of Renilla and firefly luciferase activities using the Dual Luciferase kit.

Formaldehyde cross-linking and chromatin immunoprecipitation. Formaldehyde cross-linking and chromatin immunoprecipitations were performed as described. ${ }^{18}$ The chromatin solution was immunoprecipitated with sheep anti-p53 serum (Ab7, Calbiochem, San Diego, CA, USA), anti-p53 (D01), anti-E2F-5 (Santa Cruz, E-19) or no antibody as negative control. Cyclin B1 first intron was amplified as negative control as described. ${ }^{18}$

Primers used for the amplification of the different regulatory regions are listed in Supplementary Table 3.

Cell cycle analysis. Samples were collected over the indicated time points and fixed in $70 \%$ ethanol overnight. Fixed cells were treated with RNase for 20 min before addition of $5 \mu \mathrm{g} / \mathrm{ml} \mathrm{PI}$ and analyzed by FACS.

Immunofluorescence and immunocytochemistry. Cells were seeded onto glass coverslips (Marienfeld laboratory glassware, LaudaKönigshofen, Germany) at $5 \times 10^{4}$ cells per $\mathrm{ml}$ in a 6-well plates, transfected and fixed $48 \mathrm{~h}$ later with $4 \%$ paraformaldehyde in PBS for $30 \mathrm{~min}$ at room temperature (RT). Cells were permeabilized with $1 \%$ Triton X-100 in PBS for $10 \mathrm{~min}$. After washing with PBS, the coverslips were incubated with p21 antibody (Santa Cruz Biotechnology) and/or caspase-3 (Alexis), E2F5 (Santa Cruz Biotechnology, E-19) diluted in $5 \% \mathrm{BSA} / \mathrm{PBS}$ for $1 \mathrm{~h}$ at RT. For immunofluorescence they were then washed twice with $0.02 \%$ Tween-20 and $1 \%$ BSA in PBS, followed by incubation with Alexa Flour 488 (rabbit) and Alexa Fluor 594 (mouse) conjugated secondary antibodies (Molecular Probes Inc., Eugene, OR, USA) for $30 \mathrm{~min}$ at RT. After washing three times with $0.02 \%$ Tween-20 and $1 \%$ BSA in PBS, the coverslips were counterstained with DAPI 5 min and mounted with Vectashield (Vector Labs, Burlingame, CA, USA). Cells were examined under a Zeiss LSM 510 laser scanning fluorescence confocal microscope (Zeiss, Wetzlar, Germany). For immunocytochemistry, cells were incubated with peroxidase inhibitor before primary antibody incubation. Protein staining was revealed through DAB enzymatic reaction while nuclei were counterstained with hematoxylin.

\section{Conflict of Interest}

The authors declare no conflict of interest.

Acknowledgements. We are grateful to Gerolama Condorelli for kindly providing cell lines. The support given by the AIRC-ROC to the oncogenomic platform and by the AIRC to GB, SS, GF, SDA, FF, by the Ministero della Sanita and by the Fondazione Veronesi was greatly appreciated. SD holds a fellowship from Italian Association for Cancer Research (FIRC). We thank G. Del Sal for providing plasmids.

1. Hollstein M, Sidransky D, Vogelstein B, Harris CC. p53 mutations in human cancers Science 1991; 253: 49-53.

2. Hainaut $\mathrm{P}$, Hollstein $\mathrm{H} . \mathrm{p5} 3$ and human cancer: the first ten thousand mutations. Adv Cancer Res 2000; 77: 81-137.
3. Ory K, Legros $\mathrm{Y}$, Auguin $\mathrm{C}$, Soussi T. Analysis of the most representative tumourderived p53 mutants reveals that changes in protein conformation are not correlated with loss of transactivation or inhibition of cell proliferation. EMBO J 1994; 13: 3496-3504.

4. Bullock AN, Fersht AR. Rescuing the function of mutant p53. Nat Rev Cancer 2001; 1: $68-76$.

5. Dittmer D, Pati S, Zambetti G, Chu S, Teresky AK, Moore M et al. Gain of function mutations in p53. Nat Genet 1993; 4: 42-46.

6. Oren M, Rotter V. Mutant p53 gain-of-function in cancer. Cold Spring Harb Perspect Biol 2010; 2: a001107.

7. Sigal A, Rotter V. Oncogenic mutations of the p53 tumor suppressor: the demons of the guardian of the genome. Cancer Res 2000; 60: 6788-6793.

8. Blandino G, Levine AJ, Oren M. Mutant p53 gain of function: differential effects of different p53 mutants on resistance of cultured cells to chemotherapy. Oncogene 1999; 18: 477-485.

9. Bossi G, Lapi E, Strano S, Rinaldo C, Blandino G, Sacchi A. Mutant p53 gain of function: reduction of tumor malignancy of human cancer cell lines through abrogation of mutant p53 expression. Oncogene 2006; 25: 304-309.

10. Cadwell C, Zambetti GP. The effects of wild-type p53 tumor suppressor activity and mutant p53 gain-of-function on cell growth. Gene 2001; 277: 15-30.

11. Adorno M, Cordenonsi M, Montagner M, Dupont S, Wong C, Hann B et al. A Mutant-p53/ Smad complex opposes p63 to empower TGFbeta-induced metastasis. Cell 2009; 137: 87-98

12. Fontemaggi G, Dell'Orso S, Trisciuoglio D, Shay T, Melucci E, Fazi F et al. The execution of the transcriptional axis mutant p53, E2F1 and ID4 promotes tumor neo-angiogenesis. Nat Struct Mol Biol 2009; 16: 1086-1093.

13. Frazier MW, He X, Wang J, Gu Z, Cleveland JL, Zambetti GP. Activation of c-myc gene expression by tumor-derived $\mathrm{p} 53$ mutants requires a discrete $\mathrm{C}$-terminal domain. $\mathrm{Mol} \mathrm{Cell}$ Biol 1998; 18: 3735-3743.

14. Lin J, Teresky AK, Levine AJ. Two critical hydrophobic amino acids in the N-terminal domain of the p53 protein are required for the gain of function phenotypes of human p53 mutants. Oncogene 1995; 10: 2387-2390.

15. Olive KP, Tuveson DA, Ruhe ZC, Yin B, Willis NA, Bronson RT et al. Mutant p53 gain of function in two mouse models of Li-Fraumeni syndrome. Cell 2004; 119: 847-860.

16. Chicas A, Molina P, Bargonetti J. Mutant $p 53$ forms a complex with Sp1 on HIV-LTR DNA. Biochem Biophys Res Commun 2000; 279: 383-390.

17. Sampath J, Sun D, Kidd VJ, Grenet J, Gandhi A, Shapiro LH et al. Mutant p53 cooperates with ETS and selectively up-regulates human MDR1 not MRP1. J Biol Chem 2001; 276: 39359-39367

18. Di Agostino S, Strano S, Emiliozzi V, Zerbini V, Mottolese M, Sacchi A et al. Gain of function of mutant $\mathrm{p} 53$ : the mutant $\mathrm{p} 53 / \mathrm{NF}-\mathrm{Y}$ protein complex reveals an aberrant transcriptional mechanism of cell cycle regulation. Cancer Cell 2006; 10: 191-202.

19. Di Como CJ, Gaiddon C, Prives C. p73 function is inhibited by tumor-derived p53 mutants in mammalian cells. Mol Cell Biol 1999; 19: 1438-1449.

20. Strano S, Munarriz E, Rossi M, Cristofanelli B, Shaul $Y$, Castagnoli $L$ et al. Physical and functional interaction between p53 mutants and different isoforms of p73. $\mathrm{J} \mathrm{Biol} \mathrm{Chem}$ 2000; 275: 29503-29512.

21. Strano S, Fontemaggi G, Costanzo A, Rizzo MG, Monti O, Baccarini A et al. Physical interaction with human tumor-derived p53 mutants inhibits p63 activities. J Biol Chem 2002; 277: 18817-18826.

22. Strano S, Blandino G. p73-mediated chemosensitivity: a preferential target of oncogenic mutant p53. Cell Cycle 2003; 2: 348-349.

23. Will K, Warnecke G, Wiesmüller L, Deppert W. Specific interaction of mutant p53 with regions of matrix attachment region DNA elements (MARs) with a high potential for baseunpairing. Proc Natl Acad Sci USA 1998; 95: 13681-13686.

24. Göhler T, Jäger S, Warnecke G, Yasuda H, Kim E, Deppert W. Mutant p53 proteins bind DNA in a DNA structure-selective mode. Nucleic Acids Res 2005; 33: 1087-1100.

25. Ambros V. The functions of animal microRNAs. Nature 2004; 431: 350-355.

26. Kumar MS, Lu J, Mercer KL, Golub TR, Jacks T. Impaired microRNA processing enhances cellular transformation and tumorigenesis. Nat Genet 2007; 39: 673-677.

27. Lu J, Getz G, Miska EA, Alvarez-Saavedra E, Lamb J, Peck D et al. MicroRNA expression profiles classify human cancers. Nature 2005; 435: 834-838.

28. Calin GA, Croce CM. MicroRNA signatures in human cancers. Nat Rev Cancer 2006; 6: $857-866$

29. Croce CM. Causes and consequences of microRNA dysregulation in cancer. Nat Rev Genet 2009; 10: 704-714

30. Rakhilin SV, Olson PA, Nishi A, Starkova NN, Fienberg AA, Nairn AC et al. A network of control mediated by regulator of calcium/calmodulin-dependent signaling. Science 2004; 306: 698-701.

31. Saini HK, Griffiths-Jones S, Enright AJ. Genomic analysis of human microRNA transcripts. Proc Natl Acad Sci USA 2007; 104: 17719-17724.

32. DeGregori J, Johnson DG. Distinct and overlapping roles for E2F family members in transcription, proliferation and apoptosis. Curr Mol Med 2006; 6: 739-748.

33. Dimova DK, Dyson NJ. The E2F transcriptional network: old acquaintances with new faces. Oncogene 2005; 24: 2810-2826. 
34. Coleman ML, Marshall CJ, Olson MF. Ras promotes $\mathrm{p} 21$ (Waf1/Cip1) protein stability via a cyclin D1-imposed block in proteasome-mediated degradation. EMBO J 2003; 22 2036-2046.

35. Suzuki A, Tsutomi Y, Miura M, Akahane K. Caspase 3 inactivation to suppress Fasmediated apoptosis: identification of binding domain with p21 and ILP and inactivation machinery by p21. Oncogene 1999; 18: 1239-1244.

36. Husted S, Søkilde R, Rask L, Cirera S, Busk PK, Eriksen J et al. MicroRNA expression profiles associated with development of drug resistance in ehrlich ascites tumor cells. Mol Pharm 2011; Sep: 21.

37. Moskwa P, Buffa FM, Pan Y, Panchakshari R, Gottipati P, Muschel RJ et al. miR-182mediated downregulation of BRCA1 impacts DNA repair and sensitivity to PARP inhibitors. Mol Cell 2011; 41: 210-220.

38. Galluzzi L, Morselli E, Vitale I, Kepp O, Senovilla L, Criollo A et al. miR-181a and miR-630 regulate cisplatin-induced cancer cell death. Cancer Res 2010; 70: 1793-1803.
39. Skomedal H, Kristensen GB, Lie AK, Holm R. Aberrant expression of the cell cycle associated proteins TP53, MDM2, p21, p27, cdk4, cyclin D1, RB, and EGFR in cervica carcinomas. Gynecol Oncol 1999; 73: 223-228.

40. Wong SC, Chan JK, Lee KC, Hsiao WL. Differential expression of p16/p21/p27 and cyclin D1/D3, and their relationships to cell proliferation, apoptosis, and tumour progression in invasive ductal carcinoma of the breast. $J$ Pathol 2001; 194 35-42.

41. McKenzie PP, Danks MK, Kriwacki RW, Harris LC. p21Waf1/Cip1 dysfunction in neuroblastoma: a novel mechanism of attenuating G0-G1 cell cycle arrest. Cancer Res 2003; 63: 3840-3844.

42. Strano S, Dell'Orso S, Di Agostino S, Fontemaggi G, Sacchi A, Blandino G. Mutant p53: an oncogenic transcription factor. Oncogene 2007; 26: 2212-2219.

43. Weisz L, Oren M, Rotter V. Transcription regulation by mutant p53. Oncogene 2007; 26: $2202-2211$.

Supplementary Information accompanies the paper on Cell Death and Differentiation website (http://www.nature.com/cdd) 